\title{
The Political Embodiment of AIDS: Between Individual and Social Bodies in Colm Tóibín's The Story of the Night and The Blackwater Lightship
}

\author{
Guillermo Severiche \\ New York University, USA \\ severicheguillermo@gmail.com
}

Copyright (c) 2017 by Guillermo Severiche. This text may be archived and redistributed both in electronic form and in hard copy, provided that the author and journal are properly cited and no fee is charged for access.

\begin{abstract}
By analyzing two novels The Story of the Night (1996) and The Blackwater Lightship (1999) by the Irish writer Colm Tóibín, this article proposes the concept of the sick body as an "organic allegory." Although both novels are set in different places at different times (Argentina in the 1980s and Ireland in the 1990s), they build their stories around a main character who lives with AIDS. The "organic allegory" refers to a discursive-stylistic strategy that establishes a political connection between the personal drama of the dying body and the social framework in which the story takes place. In this way, this article aims to reveal the political-corporeal dimension of these novels and to empower the body as highly political device used in literary production, both conceptually and discursively. By addressing an individual physical tragedy as one of the elements of the parallel, Tóibín's texts provide to the social drama a carnal dimension, a corporeal way to experience a political, cultural, and economic transition. Through a comparative analysis and close-reading, the examination of both texts unveils the potential of (sick) bodies as formal devices to "understand" and present a political statement.
\end{abstract}

Key Words. Colm Tóibín, The Body, Irish Literature, Neoliberalism, Illness, AIDS

Resumen. Al analizar las dos novelas The Story of the Night (1996) y The Blackwater Lightship (1999) escritas por el irlandés Colm Tóibín, este artículo propone el concepto del cuerpo enfermo como una "alegoría orgánica". Aunque ambas novelas están ubicadas en diferentes lugares y épocas (la Argentina en la década de 1980 e Irlanda en 1990), ellas construyen sus historias alrededor de un personaje principal que vive con SIDA. La "alegoría orgánica" refiere a una estrategia discursivo-estilística que establece una conexión política entre el drama personal del cuerpo muriente y el marco social en el que la historia tiene lugar. De esta forma, este artículo se propone revelar la dimensión política-corporal de estas novelas y empoderar el cuerpo como un aparato altamente político utilizado en la producción literaria, tanto conceptual como discursivamente. Al referir a la tragedia física de un individuo como uno de los elementos de un paralelo, los textos de Tóibín le dan al drama social una dimensión carnal, un modo corporal de experimentar una transición política, cultural y económica. A través de un análisis comparativo y una lectura detenida, el estudio de ambos 
textos descubre el potencial de los cuerpos (enfermos) como aparatos formales para "entender" y presentar una declaración política.

Palabras clave. Colm Tóibín, el cuerpo, literatura irlandesa, neoliberalismo, enfermedad, SIDA

After the recognition gained with his previous novels (The South [1990] and The Heather Blazing [1992]), the writer Colm Tóibín explored what then (in the mid-1990s) was a growing trend in Irish narrative: a re-configuration of the Irish traditional family and its religious values in confrontation with (homo)sexuality. In fact, Tóibín came out as a gay man in 1993, the same year when homosexuality became decriminalized in Ireland and a few years before he published his first novel with a gay man as a leading character. Sexuality, tradition, family, and religion have always been important factors that define Tóibín's writing. From his first novel (The South) to the most recently published one (Nora Webster [2014]), his stories inscribe deep concerns regarding the negotiations between the intimate and the communal, the past and the present, the bodily-driven desires and the mandate of tradition. Tóibín's texts focus on the transition, reconciliation, and adaption of individuals and communities into new models of life.

His two novels The Story of the Night (1996) and The Blackwater Lightship (1999) are highly eloquent, since they are not only the first two texts in which he portrays a gay male character, but also the first in which he discusses AIDS. In this article, I focus on the representation of the sick body and its political dimension. Particularly, I observe how illness is not displayed in these works as a static condition that haunts bodies, but rather as an "organic allegory" that carries bodies to their inevitable decline. Its allegorical condition is strongly related to the broader social framework that these novels construct while also focusing on the individual drama of the leading characters. These sick bodies connect their private suffering to historical, economic, and political issues. Thus, in these texts, the decaying bodies represented become a means to access a bodily dimension that does not only portray a more plural decline, but also opens an alternative (more carnal) way of experiencing it.

In this sense, it is not my sole purpose to establish a simple parallel between the individual body and the social body in both novels, but to enhance the idea that through the narrative form (the devices of both texts, mostly descriptions and analogous diegetic progressions) the dying bodies and their sensations display the ulterior political tools to address a deep shift in Argentine and Irish society of the 1990s. In other words, it is possible to observe that these novels appeal to the internal dimension of the body (an impossibility to be represented through language according to Elaine Scarry); ${ }^{1}$ corporeality emerges, and gives to the political argument a skin with which to feel. It is possible to say that feeling and, above all, feeling pain and dying of a disease, represent the political statements of these novels. In Tóibín's texts, what showcases the economic and political transitions experienced by Argentine and Irish communities is not framed solely in the allegorical condition of AIDS, but in its organicity. Since the body and its gradual decay appear in a personal, intimate, and sometimes graphic manner, the parallel between the tragedy of the subject and the societal framework acquires another dimension: a corporeal one. What affects the personal body, what hurts and ultimately kills it painfully, has an equal impact in a broader perspective. The neoliberal policies and their societal effects clearly are in these novels' imagery a painful process, deeply felt in the (social) flesh.

Although Scarry's argument of the un-representability of the body's internal dimension has been largely accepted, Ann Jurecic in Illness as Narrative (2012) claims that 
most of her arguments may be valid in regard to torture, but not for all forms of pain. Since Jurecic's concern deals with chronic pain and disease in literature, she opens again the question about the validity of the literary expression to represent them effectively (Jurecic 2012: 44). Actually, Jurecic re-directs the question not completely to the modes that make pain representable in literature, but rather more to the necessity of studying its reception. She assumes that the representation of pain and disease are a given, due to the extensive number of writers that have registered their own sufferings in their works. Echoing Veena Das, Jurecic affirms that "transactions between body and language ... allow for the construction of pain's meaning." As she explains:

In Scarry's framework, language fails because it cannot refer to a pain that is objectively knowable by another. Das, however, does not expect language to name pain as an objective reality. She maintains that expressions of pain perform in the imaginative register, by which she means that, because pain cannot be fully expressed or known, approximate understanding is always constructed imaginatively. (2012: 62)

In this sense, pain can be represented, but only with the support of imagination. In other words, corporeal representations require some crafting that balances the internal dimension of the body and the materiality of the artistic discourse.

So then, how has the imaginative discourse managed to represent AIDS and its corporeal dimension? And in which ways does this crafting relate to their sociopolitical context? Lina Meruane, concerned with the metaphorical construction of AIDS in literary production in Latin America, affirms that the language of metaphor rather than reflecting the reality of the disease, it constructs it in a symbolic manner. ${ }^{2}$ She argues: "[E]very illness expressed in language becomes a discursive construction, a powerful cultural artifact, a rhetorical mechanism that can produce adverse social realities" (2014: 10). Moreover, for Meruane, AIDS narratives present a symbolic return home as a constant metaphorical construction, "a demand that the homeland act like one and take them in" (50). Due to a claim for inclusion and the proximity of death, the authors in the AIDS narratives she studies perform a sort of a reverse migration.

This metaphorical construction of AIDS explained by Meruane has as a point of departure: the idea that disease in literary discourse functions as a sociopolitical device. ${ }^{3}$ The political and literary management of disease and its corporeal representations have a long history of critical discussion. ${ }^{4}$ Antoine de Baecque's study of the body's representations in literary, political, and historical texts in Eighteenth-Century France may serve as a reference to phrase one of the oldest metaphors in political theory: the personal body as the social body. To talk of a community as a singular organic body has been useful to scholars, men of letters, and politicians, since this allegory functions as a means to understand and manage the broader and more complex group of people. In other words, to introduce a society as an organism that reunites many individualities makes the management of the community comparable to the scientific management of the body. As he explains:

The metaphor of the body offers ... the illusion of an organic ordering of the human community, an illusion that thus gives them a scientific claim to observe it and organize it. Finally, each body moves in a universe of bodies: the idea of a body is essentially pluralistic, so that the corporeity of society is placed at one and the same time in conjunction with the singular-body and with the pluralistic universe-body, in homogenous and complex relationships. And these relationships are not only those of membership, of size, and of inclusion but also of representation, of analogy. From 
these graduated scales of bodily imagery, both meaning and, even more important, knowledge are elicited. (Baecque 1993: 6)

It is my argument that Tóibín's novels not only offer through an individual and sick body a way to understand the community's economic and political struggles, but mostly make them even more carnal, more perceivable through the skin of the deep impact of neoliberal policies and societal shifts experienced by the Argentine and Irish people in the 1990s.

According to Kim Wallace, the new political framework that Ireland faced during this decade, the "crossing of ideological boundaries", made Irish writers "able to create imaginative spaces in which concepts of identity, community and nationality can be explored and redefined" (2000: 257). The image of the gay male became in this decade and in others a space to re-define Irishness. Novels that represent gay men also participate in the creation of new perspectives on Irish national identity. In this regard, Micheal Cronin adds that progressive changes in Irish society, like an increase in women's freedom and the LGBT individuals' visibility and political rights, appear "not as the achievements of social movements and political activism, but as issuing from the arrival, however delayed, of modernity (by which is meant liberal capitalism) in southern Ireland" (252). Irish narrative also participates in the construction of a modern, more cosmopolitan, and more connected Ireland through the inclusion and active appearance of gay characters.

The decriminalization of homosexuality in 1993 also contributed to the inclusion of gay male characters in Irish writing. The "gay community," a "previously marginalized group," was not hidden anymore; and this brought a revision of the "nation's map" within Ireland. As Eibhear Walshe points out, "this 'revisioning' is written into the pages of Irish fiction from the 1990s" (2008: 116). Tóibín was an active participant in this discussion. Trained as a journalist and, as he said, a "historian" (Luppino 2012: 467), Tóibín revisits past times in his novels: The Story of the Night is mostly set in the 1970s and 1980s in Argentina while The Blackwater Lightship takes place in 1993 Ireland (in the year of the decriminalization, six years before its publication). Tóibín's work deals with history and collective memory, creating a tension between factual and fictional elements that is not easily solved in his novels. ${ }^{5}$ His revision of recent history in Argentina and Ireland works closely with both precise historical information and a memory "funded by tribal or familial interactions". As Oona Frawley highlights, "Tóibín does this to remind us that all narratives are constructs, and that acts of imagination inform history and memory" (2008: 71).

Another important aspect that these two novels share is the intense presence of AIDS as a medical condition endured by the main characters. Among Tóibín's novels, only these two texts explore the experience of learning about and living with AIDS so deeply. The Blackwater Lightship came out three years after The Story of the Night, which reveals a moment of need for the writer to address this conflict, an interest that later disappeared. In these novels, AIDS would refer to a personal and a communal drama, an experience suffered by the individual and refracted to a familial group. In The Blackwater Lightship, as I will later explain, illness and decay speak of the transitional period taking place in Ireland during the 1990s, as if the gay male body were not only the representation for a new Irish modern identity, but also a dying body that refers to the death of the traditional Irish mindset. As Walshe explains, Tóibín is a writer "caught between two phases of cultural development" (2008: 130).

In The Story of the Night, the action takes place in the 1980s in Buenos Aires, far from Tóibín's hometown. Richard Garay, the son of an English woman and an Argentine man, tells the story using a first person narrative voice. The novel recounts almost the entire life of the main character: from a complicated childhood where he faced the death of his father, and his mother's struggles to make ends meet, through his years at college, first jobs, and sexual 
encounters. In the background, he depicts the years of the last military dictatorship (19761983), the Malvinas/Falkland Islands war, and the return to democracy with the elected president Raúl Alfonsín. Later, he befriends an American couple, Susan and Donald Ford, two American CIA agents. They actively participate in the political scene that would define who the next president of Argentina will be. Garay works for them as an interpreter and consultant. One of his most important jobs is to collaborate and assist a group of American economists from the IMF who are interested in the series of privatizations that will eventually take place. In fact, Garay witnesses and participates in the corrupt transactions in which state companies are sold to foreign investors. At the same time that the political and economic scenario is built, Garay refers to his intimate life as a gay man: his visits to a bathhouse, his lovers and sexual encounters, and finally, his relationship with Pablo Canetto, the younger member of a wealthy and influential family. Once Garay seems to reach a general stability in his financial and emotional life, Pablo leaves him, and an intense chest pain and constant coughs send him to hospital. Garay learns that he has contracted HIV and that his immune system, which has allowed a serious pneumonia to develop, is compromised. Completely shocked, Garay tries to return to his life knowing that no cure exists and that death is close. Finally, Garay meets Pablo again at a doctor's office and finds out that he has also been infected. The couple reunites and decides to face the new condition of their lives together.

One of the most important narrative devices deployed by the novel is the parallel construction of two story lines: on one hand, the personal drama of the main character (the death of his parents, his sexual discoveries, his relationship with Pablo, and finally the first months of living with AIDS) and, on the other hand, the political and economic transition experienced by Argentine society (the dictatorship, the Falklands war, the return of democracy, the series of privatizations, and the election of Carlos Menem as new president in 1989). Although different, these two narrative lines do not remain separated: Garay, who tells the story from his own experience, functions as a pivot that connects both spheres of the intimate and the public. While the Argentine political and economic infrastructure gets fragile and vulnerable, Garay's own body starts to decay. The allegorical representation also echoes Susan Sontag's reading of AIDS as the entrance of an invader (foreign interests and investors) that destroys from within (a series of privatizations with the support of a corrupt local elite) the totality of the body's wellbeing (the national industry and economic structure). This allegorical construction transforms the first symptoms into signals of an inevitable end for both storylines: the death of Garay's body and the destruction of the national economy, which ultimately led the country into a deep crisis in 2001. By embodying in Garay's sick body the implementation of neoliberal policies in the Argentine system, the novel makes a public tragedy part of the personal world, told in first person, felt in the character's own skin.

Tóibín's interest with Argentina came after his years as a journalist in Buenos Aires, following the trial of the military heads who were in charge during the dictatorship. The article that he wrote was compiled in the book The Trial of the Generals: Selected Journalism 1980-1990 (1990). Tóibín affirms that the novel came to him as a "confessional novel" that would crudely just tell the story from the first person (O'Toole 2008: 194). In The Story of the Night, Tóibín presents highly accurate research regarding the events that took place in Argentina and neighboring countries during the 1980s in order to provide a strong and verisimilar scenario to the story: torture and abduction of citizens by the dictatorial Argentine government (Tóibín 2005: 8); the World Cup in 1978; the fall of Salvador Allende in Chile in 1973 (161); Galtieri and the Falklands war in 1982 (68); the presence of the Madres de Plaza de Mayo and the first discussions about the desaparecidos (123); the inflation and economic crisis by the end of the 1980s; the description of national industries and the importance of the oil companies; the figure of Carlos Menem and the conservative wing of Peronism; etc. What 
the novel depicts is the insertion of neoliberalism in Argentina, which later defined the entire decade of the 1990s.

The last military dictatorship (1976-1983) not only implemented violence, torture, a systematic genocide and abduction to discipline an entire population, but it also did so in order to prepare the groundwork for the emergence of neoliberal policies in Argentina. As Maristella Svampa explains, a shift in the economic and social infrastructure started during the last Argentine military dictatorship, which can also be related to other similarly repressive governments in Latin American history during the second half of the Twentieth Century. According to her, the dictatorship reshaped the material grounds of the society by putting in motion a socio-economic restructuration program (2005: 22-23). The dictatorship introduced deeps reforms based on the importation of goods and capital that interrupted national industrialization and internal production, which in turn promoted a strong indebtedness in both the public and private sectors to foreign entities. Politics not only destroyed the basis of the possibility of a national coalition, but also established the precepts for the arrival of a dominant system controlled by some national economic groups, but mostly by outside international groups.

Once the dictatorship ended, the return of democracy with President Raúl Alfonsín (1983-1989) heralded a complicated time characterized by a devastated economy and hyperinflation. When a new crisis arose, relationships between the State and foreign companies became a "convenient solution" (Svampa 2005: 31). The discourse of neoliberalism found its place at this time in a vulnerable country, and was accepted as the unique solution for all problems. Carlos Menem's presidency (1989-1999) promoted a new model for the country, based basically on liberal strategies that dismantled and delegitimized the previous model of a populist national direction. Argentina's economy became increasingly impoverished and the country became a land open to investments and importation, deeply affecting local industry (2005: 36). However, the privatizations of national industries that took place at this moment were not "free of corruption" at all. Only the Argentine elite benefited from the business deals that were established in these years. Menem promoted the purchase of historical Argentinian industries, such as YPF and Telefónica. Clearly, the sale of YPF, the oil company, was a milestone in the success of neoliberalism in this vulnerable country. ${ }^{6}$

Tóibín portrays the historical scenario of the 1970s, 1980s and beginning of 1990s in Argentina throughout the entire novel. By becoming an ally of Donald and Susan Ford, Garay witnesses different meetings of the elite that would later decide their presidential candidate. He was fascinated by the Fords' power and influence:

I still believe that they were involved in every cent which the United States put into the campaign for the election of Carlos Menem and maybe other candidates. I do not know ... how much real power they had. But they could make decisions, I was sure, without consulting anybody. I never once underestimated them. ... I was excited by them, by the idea that they had a hidden agenda here, by the idea that they were outsiders. (83)

Garay's close collaboration with the Fords leads him to participate in the corrupt transactions in which several national companies such as YPF were sold. After Garay becomes an important independent consultant with his own office, he receives a visit from one of the State agents involved in the YPF privatization. He asks Garay to apply for a contract in which Garay himself would claim to provide a service never given and then receive a share of a large corrupt profit (Tóibín 2005: 155). Garay agrees to go ahead (175), although later he seems to regret it: 
When the second half of the money arrived, I became worried. I felt that I had lost my nerve. I had visions of us being caught, our photographs in the newspapers as we were led away. Signing the contract and getting paid seemed easy to live with, but taking money for services never provided was something else. (186)

Both Garay's deep connection with the Fords and his participation in the corrupt privatizations make him one of the protagonists in the transition into a new political structure in Argentina. This is one of the "stories of the night", one of the stories of darkness that he experiences. Like the Fords, Garay keeps silent about the manipulation of power and the perverse interests of the globalized market in running the country. However, as Kim Wallace explains, this attitude does not prevent Garay from living in the flesh the destruction of the national structure to which he has contributed. The novel suggests that Garay retreats from understanding or communicating. But "the suppression of the political narrative does not free the individual from the impact of political forces" (Wallace 2000: 266). Indeed, the political and economic aspects of the novel are developed alongside an intimate story which later ends with Garay's discovering of his HIV-positive condition. This is the other story of the night.

Although sickness and pain appear mostly in the second half of the novel, corporeality has always been present in various forms. From the beginning, Garay's (homo)erotic desire and first sexual encounters are clearly exposed: his interest in his father's body (Tóibín 2005: 16), his encounters with his cousin's friends in La Pampa (25), and his first visits to the gay sauna (66). But corporeality also appears in other ways: torture and pain (the experience of the Chilean refugees in Barcelona) (51); the visualization of his parents' corpses rotting in their coffins $(30,63)$; a homoerotic display of domination by Donald in the lockers (137); and his attempt to sleep with Susan (160). Embodiment is everywhere at every moment. Sexual desire, pain, and finally disease are constant references made by the narrative voice. Garay becomes aware of the corporeal presence of others and its impact on his own, as if the story were told also through his body.

When AIDS first appears in the novel, it seems to be something occurring far from Garay's reality: something heard, read in an American newspaper (197). But later it becomes more "real" when Pablo's friends, both living with AIDS, visit Buenos Aires. ${ }^{7}$ One of them, Mart, essentially has no immune system. Garay encounters for the first time what it means to live with AIDS: the medication, the constant medical check-ups, the body's vulnerability, the opportunistic infections, etc. He also learns of the catastrophe that the disease has caused within the gay community in San Francisco, Pablo's friends home city. Later, Garay listens to Pablo telling his personal story with Frank, his former partner at the time when he lived there, who has already died (250). After Pablo's friends leave, Garay focuses again on the contracts and Menem's election. Later, Mart dies, and Pablo travels to California to attend the funeral while Garay stays to work. Some days after he tries to contact Pablo, but he has disappeared. Then, Garay finds out that Pablo has not only returned to Argentina, but refuses to talk to him. The relationship seems to be over. In a spontaneous reaction, Garay goes to New York to spend some days with a colleague and lover when the first symptoms appear. He feels great difficulty breathing and a sharp pain in his back; he coughs terribly. He decides to return to Buenos Aires as his condition worsens. These are some of the symptoms he experiences:

Each time I coughed I felt a sharp pain in my back. I felt hot and sweaty. I lay there trying to stop but I had no control over my breathing. ... I felt a burning in my lungs. (286)

My skin was on fire and I had a terrible thirst. ... I braced myself each time, I knew how sharp the pain was going to be, as though my lungs were going to 
explode. ... Every bone in my body was sore, and I felt that I was not going to be able to continue breathing. (288)

The detailed description of these symptoms represents an attempt to portray an intimate corporeal experience from the first-person perspective. Once Garay arrives in Buenos Aires, he goes to the hospital and learns that he has a severe pneumonia. The doctors run tests and discover he is HIV positive. Garay's corporeal decay is later emphasized in the visualization of his own death:

I lay back thinking that this would be the end, then, that my body would be covered in a sheet and pushed on a trolley to the morgue, that before then I would spend weeks, maybe months, languishing here or at home, becoming thinner and weaker, waiting for the long ordeal that would result in being alive one minute, alert, with a full memory, and the next minute dead, everything gone. (294-295)

These corporeal accounts of Garay's body, alongside all other physical sensations deployed in the novel (i.e., sexual pleasure and arousal), can be seen as a formal device to provide an intimate, carnal account about what was happening in the broader framework. The text's interest in addressing intensively the condition of the body, its pain and pleasure, equals the development of the economic and political depiction. As other critics have pointed out, although not sufficiently (Caserio 2006; Naughton 2010), ${ }^{8}$ the novel suggests that Garay's corporeal suffering becomes an allegorical result of the process taking place in the country's economy and political infrastructure. If it is possible to affirm that the individual body functions as a metaphor for the impact of neoliberal policies on the Argentine society, Tóibín's highest contribution is to provide to the social tragedy an intimate narrative, an "organic" one, a close narrative perceivable in the skin, experienced in the flesh by a particular person, by a particular body. The novel's various accounts of the body's feelings and sensations make the social drama something that happens also in the insides, a reality enclosed in the way we experience it through the skin. The text presents a political statement by appealing to the internal dimension of the body through the descriptions of a parallel narrative construction.

When Tóibín was asked in an interview about the strong connections between The Story of the Night and his next novel The Blackwater Lightship, the interviewer also pointed out that beyond their similarities in the theme that they explore, they work from different perspectives. In fact, they are stylistically different. Tóibín responded that although he tried to avoid writing The Blackwater Lightship, he could not help it. He even added that in the second novel (something we could also perceive in the The Story of the Night) nationality is inscribed in the characters themselves: "[M] emory is a thing they saw on television, or what they remembered about their children, and that there's no nation in the book, except that the characters are the nation!" (O'Toole 2008: 195).

Declan's body in The Blackwater Lightship becomes an allegory that refers to a cultural process that was taking place in Ireland during the 1990s. In this novel, the sick body functions as an allegory for the transition from a traditional familial mentality tied to religious morality to a modern mindset more connected with a cosmopolitan and economically prosperous nation.

The Blackwater Lightship is mainly set in Tóibín's own hometown, Wexford, far from the capital city of Dublin. After learning that her brother has been dealing with AIDS for several years, Helen decides to comply with his wishes to stay with his grandmother at her house near the cliffs in Wexford after he leaves the hospital. Declan also asks Helen to tell their mother, Lily, about his condition. Declan's wishes awaken past family issues since they 
all spend several days all together again at the grandmother's house. Helen has completely disconnected herself and her family from her mother and grandmother, due to past misunderstandings and resentments, but Declan's situation forces them to face each other. The three of them, each one representing different generations of Irish women, endure not only their own issues but also the fact that Declan has practically excluded them from his life. Like his female relatives, Paul and Larry, two of Declan's gay friends, also join him in his return to the familial house. They demonstrate a deeper knowledge about the disease and about Declan's life itself. After some days of tension, Helen revisits her memories of her childhood. She remembers her father alone and sick in the city's hospital while their mother prevented them from seeing their dying dad. Helen confronts Lily, who is also hurt by her daughter's continuous exclusion of her (both the mother and grandmother were not invited to Helen's wedding and have barely seen her children). Gradually Declan's condition worsens, and he has to be taken back to the hospital. On their way there, Helen and Lily seem to find a starting point for reconciliation. Declan's body will soon disappear, but some hope remains in the mother-daughter relationship.

Similar to Richard Garay's corporeal condition, Declan's illness seems to represent a broader social shift taking place in Ireland. He embodies the painful transition from a traditionally isolated Catholic nation into a European, economically-promising, and cosmopolitan country. According to Matthew Ryan, the fact that all of these gay characters visit the Wexford coast far from the capital city Dublin entails a project of "textual reterritorialization" which creates a tension between tradition and modernity. Both Declan's "families" (Paul and Larry on one side, Helen, Lily, and his grandmother on the other) live together: "A reformation of the family around homosexual relationships is not represented here as outside the moral frame of Catholicism" (Ryan 2008: 28). Rather than clashing or superseding, Ryan highlights how "tradition" and "modernity" intersect. But this is not an easy achievement in the novel. The characters develop a deeper understanding and trust as Declan's body worsens.

From the beginning the two groups differentiate themselves. Declan's female relatives belong to a more local, rural world tied to traditional family compositions. For example, Helen is a school director with a husband and two children, Lily is a successful sales agent in a local company who never married again after her husband's death, and the grandmother lives peacefully by the Irish coast in a small town. On the other hand, Declan's best friends are part of a new phase of Irish society, which allows gay men to have an honest lifestyle in accordance with their sexuality inside and outside of Ireland - Paul has a long-term relationship with a French man and lives in Belgium while Larry is a successful interior decorator. As many critics have pointed out (Böss 2005; Carregal-Romero 2012; Cronin 2004; Persson 2007; Walshe 2008), the encounter of these two groups of people supports the reading of the novel as depicting the shift taking place in 1990s Ireland.

There are other important details that reveal the novel's configuration of the changing environment in Irish morality and mentality. When talking to Declan's sister and grandmother, Larry tells the family about his frequent and intense participation in the activist struggle for LGBT rights:

I was involved in a gay group in Dublin, and we organised fund-raising and we started news sheet, and we had meetings all the time. I helped out a bit, and I was around a lot, so the time Mary Robinson invited gay men and lesbians to Áras an Uachtaráin, I was on the list and I couldn't say no. (144)

Larry refers here to the president Mary Robinson's (1990-1997) well-known invitation of G.L.E.N. (the Gay and Lesbian Equality Network) to visit her in the presidential residence. 
Popular for her inclusion of marginalized groups and communities (the decriminalization of homosexuality took place during her presidency), Robinson's term seems to have opened the door for the discussion of inclusion of minorities and the criticism of some of the Catholic Church's political stances.

While Larry's story refers to the political background happening in Ireland, Paul speaks from another sort of experience. His long-term relationship with François made him discover how more "open-minded" families from continental Europe deal with homosexuality, something that seemed still not possible in Ireland:

When we got together, ... François' parents were just unbelievable. They bought a big double bed for us and put it in François' room. I don't think he had a single moment's problem with them about being gay. We saw them often. We usually stayed with them on a Saturday night, or saw them on Sunday. They were our best friends. (168)

Paul's story contrasts with Declan's own relationship with his family. The contrast that Paul's experience creates contributes to the challenge of Irish traditional views on sexual and emotional relationships. He even tells the story of a priest from Brussels who agrees to marry Paul and François in a secretive ceremony, something questioned by all the Irish people with whom he has shared the story (Tóibín 1999: 176). The priest even says, "Welcome to the Catholic Church" (173). Helen cannot help questioning the validity of such a ceremony since the Vatican would not allow it, to which Paul responds: "That's why I left this country, remarks like that. French people, even Belgian people, never talk like that" (176). The different conceptions on family and religion clash as part of a painful process of adaption.

While these tensions between Irish traditional views and other, more modern ones are depicted, the novel also presents Declan's bodily deterioration. Helen, from whose perspective the story is told, observes with astonishment the decay of her brother. As in The Story of the Night, the account of the body's decay and painful journey are detailed and constant: "When Helen looked at Declan in this light, she saw for the first time how sick he was, how tight and drawn the skin on his face was, how tired his eyes seemed, and how shrunken his whole body had become" (108). After losing the sight in one eye (200), Declan's state worsens even more. Vomiting and diarrhea are the first symptoms (221), which soon turned into strong and painful abdominal spasms. Tóibín's text constructs an entire scenario to present the body's pain, which gives to this experience an important place in the narrative development:

In the hour after midnight, Declan's stomach cramps began again. He had been sweating heavily; Helen and her mother were sitting by his bed, her mother holding a towel to wipe his brow. He had been still for a while, with his eyes open, and light coming from a covered lamp in the corner. Suddenly, he started to heave; he sat up and held his stomach, pressing hard as though to prevent the cramp coming, and then moaning under his breath in small fits and starts until it died down. (256)

Although the story does not cover Declan's death, his imminent end seems quite close. Similarly to The Story of the Night where AIDS and the decaying body function as a parallel representation of the impact of neoliberal policies in the broader societal structure, here Declan's suffering embodies the decay of a traditional mindset and conception of family, or rather, a process of adaptation into a new mentality. As previously explained, this transition can also be seen as the result of the application of neoliberal policies during the 1990s within 
a familial sphere. The phenomenon of the "Celtic Tiger", which actually refers to the gradual implementation of neoliberalism and the deep impact that its policies had in Irish political, economic, and cultural configuration, took place during the 1990s and up to 2008, a period during which Ireland experienced great economic growth. A series of factors, such as a crisis in the religious institution, new era of peace with the IRA, and the country's integration to a globalized economy, determined the rapid implementation of neoliberal policies and the subsequent "economic miracle." But, as Bertrand Maître and Christopher Whelan affirm, "the benefits of the 'Celtic Tiger' are largely illusory and a focus on conventional economic indicators conceals a picture of increased inequality, erosion of employment security, and marginalization" (2007: 139-140). However, Tóibín's writing in The Blackwater Lightship is more engaged with the cultural impact on the traditional families in Ireland rather than the economic or political structures, as is the case in the The Story of the Night.

Declan's embodiment of this shift in the Irish mindset has also been traced by different critics (Carregal-Romero 2012; Frawley 2006; Persson 2007; Ryan 2008; Yebra 2014). Among them, José María Yebra provides an interesting perspective by pointing out that Declan's sick body functions as a sort of "Christian sacrifice," witnessed and also closely suffered by the mother and the sister, who resemble the figures of the Virgin Mary and Mary Magdalene. Yebra's reading actually emphasizes Tóibín's interest in Irish Catholicism, a theme examined in several of his non-fiction books and recently in the novella The Testament of Mary (2012). Yebra explains that "Declan ... fulfils a Messianic role that Irish culture allegedly needs to confront traumatic changes. Catholic sacrifice, pain, and suffering are here re-defined in the form of AIDS or gay ostracism" (2014: 98). He also adds that Declan's body functions as an allegory of sin and punishment, and thus his corporeality could be read as "the site of Irish Catholic morality and repression, as the casualty of the Irish modernization process" (99). In fact, Tóibín himself indicates that in his novels he enacts "a forgiveness, a sort of cleansing and reconciliation, even a sort of redemption, and that the novels mimic elements of the New Testament story" (Dillon 2000: 26). Hence, rather than a representation of a social decay, the sick body in The Blackwater Lightship becomes a recipient of social changes that must be sacrificed, given away for the benefit of everybody. What Yebra's reading points out above all is that the sick body becomes a space of struggle for social processes.

Gay male characters or AIDS are not the only common elements in these two novels; the mechanism for illness and embodiment also reveal deeper societal, political, and economic shifts. Although set in two different contexts, it is possible to trace some connections between Argentina and Ireland at this point in their history. As Wallace explains: "Argentina seems analogous to Ireland with its sense of displacement when faced with the violence of its colonial/postcolonial past and the resurgence of violent conflict in the North" (2000: 265). The effects of a violent past and their transition into a new status happen through the body in both texts, as a sort of sublimation.

Again, the formal configuration of the sick body in The Blackwater Lightship encapsulates what I consider the most important contribution in Tóibín's text. Not only the parallel of the individual body with a social framework, but mostly the development of narrative devices to showcase the body's internal dimension, its pain and decay, as a political statement. In other words, this novel as well as The Story of the Night, utilizes description and parallel storylines to make the social drama a much more intimate one, a bodily one that is felt in the flesh. What these novels represent is that it is possible to understand politics through the body, that physical sensations represented in literary works can be politically charged, and that it is possible to understand and argue through sensations. In one way or another, these novels try to formulate a voice that speaks from the flesh, a sickened flesh that cries a "truth" that needs to be heard. Their device is a sick dying body that seems to burden the decline of a 
societal framework, and such decline becomes only understandable/perceivable through the skin.

\section{Notes}

${ }^{1}$ In the introduction to her book The Body in Pain (1985), Elaine Scarry argues that an unexplained and unrepresentable dimension of human suffering exists. According to her, all language is inadequate to represent pain. Moreover, she affirms, "Physical pain not only resists language but actively destroys it, causing an immediate reversion to a previous state of language, to the sounds and cries that the human being makes before learning the language" (4). Scarry also declares the almost complete absence of literary representations of pain: "Alarmed and killed by his own failure to language, the person with pain may find comfort to know that even the artist - whose life and daily habit are dedicated to refine and extend discourse reflexes - ordinarily silently surrenders to pain" (10).

2 It is difficult not to relate this idea to Susan Sontag's AIDS and Its Metaphors (1989), who sees in AIDS the invasion of an "other" (11). As Meruane explains: "The body/nation invaded or assaulted by a foreign virus that would defeat the defensive army or, in other versions, the AIDS patient as the Third-World guerrilla fighter or terrorist threatening the imagined health of the nation" (18). As we will see, this metaphorical construction also has a deep echo in Tóibín's novel The Story of the Night.

${ }^{3}$ For Judith Schlanger, the metaphorical construction of disease plays an important role for a social, political and historical rationalization. This is why the subject of a malady is "le lieu où se recoupent le plus profondément l'organisme sociologique et l'organisme historico-politique" [the place where the sociological organism and the historic-political organism] profoundly intersect (175, my translation).

${ }^{4}$ The body politic functions as a metaphor that conceives a nation as a corporate entity, similar to a human body. Although clearly referenced in the Middle Ages in Christine de Pizan's The Book of the Body Politic (1407), this metaphor already had some history in Plutarch's letter to the Roman emperor Trajan. In Flesh and Stone, Richard Sennett provides a depiction of the metaphor and its use in the political administration that can easily be compared to modern times: "The philosopher John of Salisbury gave perhaps the most literal definition of the body politic, declaring in 1159 simply that 'the state (res publica) is a body.' He meant that a ruler in society functions just like a human brain, the ruler's counselors like a heart; merchants are society's stomach, soldiers its hands, peasants and menial workers its feet. His was a hierarchical image; social order begins in the brain, the organ of the ruler. John of Salisbury in turn connected the shape of the human body and the form of a city: the city's palace or cathedral he thought of as its head, the central market as its stomach, the city's hands and feet as its houses. ... John of Salisbury wrote as a scientist; finding out how the brain works, he believed, would tell a king how to make laws. Modern sociobiology is not too far from this medieval science in its aim; it too seeks to base how society should operate on the supposed dictates of Nature. In either medieval or modern form, the body politic founds rule in society on a ruling image of the body" (Sennett 1994: 23-24).

${ }^{5}$ In regard to The Blackwater Lightship, Åke Persson refers to private memory and oral histories as a fruitful method to counter official history and problematize what actually happened. For the author, this conception of collective memory is highly performed in Tóibín's novel as a means to respond to traditional mandates and norms that shape sexuality and identity in Ireland: "[The characters'] oral histories, based on and retold from private memories, could be read as a strategy to resist dominant and official versions of what constitutes sexual identity and family; certainly the latter has been hugely important in the formation of Irish identity and Irishness" (Persson 2007: 150).

${ }^{6}$ As Roberta Villalón expands: "In the short term Argentina witnessed economic growth, high investment rates, and monetary stability, but in the longer term it experienced severe impoverishment, unemployment, income polarization, recession, and, finally, monetary and financial instability that, combined with the rollback of the state, generated a growing heterogeneous mass of unemployed people without institutional protection from either the state, the unions, or other organizations" (2007: 140). This lack of sustainability and the economic crisis reached a peak in December 2001 and resulted in massive protests, violent repression, several violent incidents that wounded or killed people, and the resignation of President Fernando de la Rúa.

${ }^{7}$ Lina Meruane highlights how the figure of the world traveler corresponds to the construction of the one that spreads infection crossing all kinds of boundaries. As she affirms: "Those travelers were the living image of a globalizing world that, having previously celebrated total movement and absolute freedom, was now, with the crisis, on high alert" (2014: 48).

${ }^{8}$ Robert Caserio's concern with the development of the Queer Fiction as a genre leaves little room to the analysis of Tóibín's The Story of the Night, its AIDS narrative deployment, and the political circumstances that surround it. Among other novels' accounts, including Tóibín's The Master (2004), Caserio only refers to the parallel individual-social bodies in The Story of the Night in the following manner: "Nationalism, global internationalism, and intensifying privatization paradoxically go together. Bodily life repeats the paradox. In 1988, the protagonist and his closeted Argentine lover discover that they are suffering from AIDS, their HIV 
infection having predated identification of the virus and their own safe-sex practices. Their experience of disease will be 'like . . . being tortured and punished'. They too will enter the realm of the disappeared; and their private story will find no adequate public hearing" (218). In the case of Gerald Naughton, he compares Tóibín's novel with James Baldwin's Giovanni's Room in order to emphasize the tensions between desire and repression and their connection with an exiled subjectivity. Although his analysis conceives a parallel existence of a private and public world, the focus is located in the concept of identity, which does not give sufficient scope to the political dimension of the bodily existence in the text: "In a novel that maps Garay's contested sexual identity onto the political vacuum of post-Falklands War Argentina, [Garay and Pablo's] relationship can only exist in private spaces that are dislocated and divorced from national politics. Like his childhood efforts to solve the dilemma of uncertain nationality through self-willed exile, Garay's very real love for Pablo can only thematically fit as an act of escape, a way of avoiding the question of his identity" (2010: 139).

\section{Works Cited}

Baecque, Antoine de. 1993. The Body Politic. Corporeal Metaphor in Revolutionary France 1770-1800. Trans. by Charlotte Mandell. Stanford: Stanford University Press.

Böss, Michael. 2005. "Belonging without Belonging: Colm Tóibín's Dialogue with the Past." Estudios irlandeses, 0. 22-29.

Carregal-Romero, José. 2012. "Colm Tóibín and Post-Nationalist Ireland: Redefining Family Through Alterity." Estudios irlandeses, 7. 1-9.

Caserio, Robert. 2006. "Queer Fiction: The Ambiguous Emergence of a Genre". Ed. James English. Contemporary British Fiction. London: Blackwell, 2006. 209-228.

Cronin, Michael. 2004. "He's My Country: Liberalism, Nationalism, and Sexuality in Contemporary Irish Fiction." Éire-Ireland, 39.3-4. (Fall). 250-267.

Dillon, Hugh. 2000. “Talking to Tóibín.” Eureka Street, 10.9. (November). 25-28.

Frawley, Oona. 2008. "The Difficult Work of Remembering: Tóibín and Cultural Memory." Ed. Paul Delaney. Reading Colm Tóibín. Dublin: The Liffey Press. 69-82.

Hanafin, Patrick. 2000. "D(e)nying Narratives: Death, Identity and the Body Politic." Legal Studies, 20.3 (September). 393-408.

Jurecic, Ann. 2012. Illness as Narrative. Pittsburgh: University of Pittsburgh Press.

Luppino, Claudia. 2012. "Art, Politics and Memory: A Conversation with Colm Tóibín." Studi Irlandesi. A Journal of Irish Studies, 2. 455-472.

Maître, Bertrand and Whelan, Christopher. 2007. "Levels of Patterns of Material Deprivation in Ireland: After the 'Celtic Tiger.'” European Sociological Review, 23.2 (April). 139154.

Meruane, Lina. 2014. Viral Voyages. Tracing AIDS in Latin America. Trans. by Andrea Rosenberg. New York: Palgrave.

Naughton, Gerald David. 2010. "Confronting the Foreigner from Within: (Sexual) Exile and Indomitable Force in the Fiction of James Baldwin and Colm Tóibín." Exploring Transculturalism. Berlin: VS Research.

O’Toole, Fintan. 2008. “An Interview with Colm Tóibín.” Ed. Paul Delaney, Paul. Reading Colm Tóibin. Dublin: The Liffey Press. 183-208.

Persson, Åke. 2007. "Do Your Folks Know that You Are Gay? Memory and Oral History as Education and Resistance in Colm Tóibín's The Blackwater Lightship." Recovering Memory. Irish Representations of Past and Present. Cambridge: Cambridge Scholar Publications. 149-169.

Ryan, Matthew. 2008. "Abstract Homes: Deterritorialisation and Reterritorialisation in the Work of Colm Tóibín." Irish Studies Review, 16.1. 19-32.

Scarry, Elaine. 1985. The Body in Pain. The Making and Unmaking of the World. New York and Oxford: Oxford University Press. 
Schlanger, Judith. 1971. Les metaphors de l'organisme. Paris: Librairie Philosophique.

Sennett, Richard. 1994. Flesh and Stone. The Body and the City in Western Civilization. New York: Norton \& Company.

Svampa, Maristella. 2005. La sociedad excluyente. La Argentina bajo el signo del neoliberalismo. Buenos Aires: Taurus.

Tóibín, Colm. 1999. The Blackwater Lightship. London: Scribner, 1999.

- 2005. The Story of the Night. A Novel. New York: Scribner, 2005 . 1990. The Trial of the Generals. Selected Journalism 1980-1990. Dublin: Raven

Arts Press.

Villalón, Roberta. 2007. "Neoliberalism, Corruption, and Legacies of Contention: Argentina's Social Movements, 1993-2006." Latin American Perspectives, 34.2. (March). 139156.

Wallace, Kim. 2000. "Dissent and Dislocation in Colm Tóibín's The Story of the Night." BELLS: Barcelona English Language and Literature Studies, 11. 257-273.

Walshe, Eibhear. 2008. “This Particular Genie: The Elusive Gay Male Body in Tóibín's Novels.” Ed. Paul Delaney. Reading Colm Tóibín. Dublin: The Liffey Press, 2008. 115-130.

Wiesenfarth, Joseph. 2009. “An Interview with Colm Tóibín”. Contemporary Literature, 50.1. (Spring). 1-27

Yebra, Jose María. 2014. "The Interstitial Status of Irish Gayness in Colm Tóibín's The Blackwater Lightship and The Master.” Estudios irlandeses, 9. 96-106.

Received: 3 August 2016 Revised version accepted: 28 February 2017

Guillermo Severiche is a fiction writer and a researcher in the area of Comparative Literature. He holds a PhD from Louisiana State University (Baton Rouge, USA), where he has taught Spanish, Film and Media, and World Literature. Currently, he holds a fellowship to participate in the MFA Program in Creative Writing in Spanish at New York University. 